\title{
ANALISIS KANDUNGAN GIZI SELAI POH LEMBONGAN OLEH-OLEH LANGKA KHAS NUSA PENIDA
}

\author{
I Wayan Karta ${ }^{1},{ }^{2}$ I Putu Suiraoka, ${ }^{3}$ Ni Made Defy Janurianti, ${ }^{4}$ I Wayan Wiwin, ${ }^{5}$ I Made Arnawa \\ ${ }^{1}$ Jurusan Teknologi Laboratorium Medis Poltekkes Kemenkse Denpasar \\ ${ }^{2}$ PUI PK Poltekkes Kemenkes Denpasar \\ ${ }^{3}$ Fakultas Pertanian Universitas Warmadewa, Denpasar, Bali, Indonesia \\ ${ }^{4}$ Jurusan Pariwisata Budaya, Universitas Hindu Negeri I Gusti Bagus Sugriwa, Denpasar, Bali, Indonesia \\ ${ }^{5}$ Yayasan Taksu Tridatu, Klungkung, Bali, Indonesia \\ *iwayankartaganesh@gmail.com
}

\begin{abstract}
Poh Lembongan mango is a typical mango from the island of Nusa Penida. During the harvest season, the fruit is abundant and not used. The use of this mango fruit needs to be researched to be used as a souvenir product by processing it into jam. This study aimed to analyze the nutritional content of the mango poh lembongan jam and test the organoleptic to determine the acceptability of the product as a souvenir.

The research method used is descriptive, namely by laboratory tests and organoleptic tests. Laboratory tests were carried out by analyzing moisture content, ash content, fat content, protein content, carbohydrate content, and vitamin $C$. Organoleptic tests were carried out to assess the aroma, taste, viscosity and, acceptability parameters of 15 panelists.

The results showed that the content of this jam was $19.649 \%$ water content; ash content $0.165 \%$; fat content $0.573 \%$; protein content $0.907 \%$, the carbohydrate content $78.705 \%$, and vitamin $C$ of $20.476 \%$. Vitamin $C$, which is relativel high in the jam, allows the product to be used as healthy food . Organoleptic tests show that the community can still accept the taste, aroma, texture allows the product to be used as healthy food. Poh Lembongan mango jam can be developed into a typical souvenir product from Nusa Penida Island.
\end{abstract}

Key words: Jam, mango poh lembongan, Nusa Penida, nutritional content, organoleptic test

\section{Pendahuluan}

Nusa Penida merupakan salah satu kecamatan yang ada di Kabupaten Klungkung, Provinsi Bali. Kecamatan ini terdiri dari tiga kepulauan yaitu pulau Nusa Penida, Pulau Ceningan, dan Pulau Lembongan. Dari tahun 2017, kecamatan ini mengalami kemajuan dalam pengembangan pariwisata. Objek wisata dan fasilitas baru mulai terbangun seiring dengan semakin meningkatnya wisatawan ke Nusa Penida. Alih pekerjaan mulai nampak yaitu yang awalnya sebagai petani, peternak beralih menjadi pekerja dalam pariwisata. Kegiatan pertanianpun mulai ditinggalkan, sehingga lahan-lahan pertanian banyak yang belum digarap.

Hal yang menyebabkan terjadinya perubahan mata pencaharian karena 
Karta, I.W., dkk.: Analisis Kandungan Gizi Selai Poh Lembongan Oleh-Oleh Langka Khas Nusa Penida

pendapatan di bidang pariwisata lebih menjanjikan dibandingkan di pertanian. Padahal kalau dilakukan sinergi antara pertanian dan pariwisata, pendapatan masyarakat tentu akan meningkat dan alih fungsi lahan dapat dikurangi. Sinergi ini sangat penting dilakukan untuk meningkatkan nilai jual hasil pertanian melalui kemajuan pariwisata. Hal ini dapat dilakukan dengan mengolah hasi pertanian menjadi produk kreatif dan bernilai guna. Salah satu hasil pertanian yang tidak termanfaatkan selama ini adalah mangga Nusa Penida, atau dikenal dengan poh nusa atau poh lembongan.

Poh Lembongan atau mangga Nusa Penida merupakan jenis mangga yang khas. Kekhasannya dapat dirasakan dari segi rasanya yang asam-asam manis, warnanya yang orange kekuningan saat matang, dan kulit buahnya yang halus. Mangga ini termasuk jenis buah musiman, karena berbuah pada akhir bulan Oktober sampai dengan Februari. Pada saat musim, buah poh nusa harganya sangat rendah dan belum dimanfaatkan menjadi produk ekonomis, serta terbuang tanpa pengolahan. Waluapun, terkadang ada masyarakat yang memanfaatkan untuk pakan ternak. Sehingga musim panen tidak banyak memberikan implikasi hasil yang banyak. Mangga poh lembongan sebenarnya dapat diolah menjadi produk olahan seperti seperti selai, manisan, dodol, wine, sirup dan kripik. Dalam penelitian ini akan dikaji mengenai hasil pengolahan mangga nusa menjadi selai. Kajian yang dilakukan yaitu uji kadar air, kadar abu, kadar lemak, kadar protein, kadar karbohidrat, dan kadar vitamin $\mathrm{C}$.

Selai merupakan produk olahan pangan yang dibuat dari buah yang telah dihaluskan atau diblender kemudian dimasak dan ditambahkan dengan gula yang memiliki tekstur lunak ${ }^{(1)}$. Selai sering digunakan sebagai pelengkap roti yang biasanya disajikan saat sarapan. Kebutuhan selai di masyarakat semakin meningkat, sehingga berbagai macam jenis selai juga dikembangkan. Roti dan selai biasanya dipakai untuk menggantikan nasi. Oleh karena itu kandungan gizi pada selai juga perlu diperhatikan dalam pembuatannya ${ }^{(2)}$. Pengolahan mangga nusa menjadi selai di Nusa Penida memiliki potensi untuk dikembangkan menjadi oleh-oleh khas Nusa Penida. Pembuatan produk oleh-oleh atau souvenir merupakan salah satu upaya strategi pengembangan pariwisata yang berkelanjutan di Nusa Penida ${ }^{(3)}$.

Mangga nusa yang memiliki rasa asam-asam manis tentu akan memberikan cita rasa yang berbeda dengan selai mangga jenis lainnya. Selain sebagai oleh-oleh, selai juga diperlukan oleh villa dan restauran untuk menu makanan khas lokal. Rasa mangga nusa yang khas menunjukkan adanya kandungan kimia seperti vitamin $\mathrm{C}$. Pembuatan selai berbahan poh lembongan perlu memperhatikan komposisi 
Karta, I.W., dkk.: Analisis Kandungan Gizi Selai Poh Lembongan Oleh-Oleh Langka Khas Nusa Penida

campurannya, sehingga memberikan nilai rasa yang enak. Berdasarkan hal tersebut, maka dalam penelitian ini dilakukan uji kandungan gizi dan uji organoleptik untuk mengetahui pendapat panelis mengenai produk yang telah dibuat.

\section{Metode Penelitian}

Penelitian ini merupakan penelitian deskriptif yang menggambarkan hasil uji kandungan kimia dan uji organoleptik pada selai poh lembongan atau mangga nusa. Pembuatan selai dilakukan di Yayasan Taksu Tridatu, Nusa Penida. Pemeriksaan kandungan kimia selai poh lembongan dilakukan di Laboratorium Analisis Pertanian Fakultas Pertanian Universitas Warmadewa. Pemeriksaan dilakukan pada kadar air, kadar abu, kadar lemak, kadar protein, kadar karbohidrat, dan kadar vitamin C. Analisis kadar air dilakukan dengan menggunakan metode pengeringan $^{(4)}$, kadar abu dilakukan dengan metode pengabuan ${ }^{(4)}$, kadar lemak dengan metode Soxhlet $^{(4)}$, kadar protein menggunakan metode Mikro-Kjeldahl ${ }^{(4)}$, kadar karbohidrat adalah analisa Carbohydrate by different, dan analisis vitamin $\mathrm{C}$ dilakukan dengan metode spektrofotometri $^{(5)}$. Uji organoleptik dilakukan dilakukan kepada 15 orang panelis dengan parameter aroma, rasa, tekstur, dan daya terima kesukaan ${ }^{(6)}$. Warna kuningnya diberikan penilaian kesukaaan, aroma dan rasa diberikan penilaian tentang adanya aroma dan rasa mangga, teksturnya diberikan penilaian tingkat kekentalannya.

Selai poh nusa dibuat dengan menghaluskan buah mangga matang yang telah didiamkan selama 3 hari. Penghalusan dilakukan menggunakan blender. Kemudian ditambahkan dengan gula sebanyak $50 \%$ dari massa bubur buah mangga. Campuran diaduk dan ditambahkan dengan perasan jeruk lemon $4 \%$, diaduk sampai kental. Selai yang telah kental didinginkan dan dilakukan pengujian.

\section{Hasil dan Pembahasan}

Hasil olahan produk selai poh lembongan dapat dilihat pada Gambar 1.

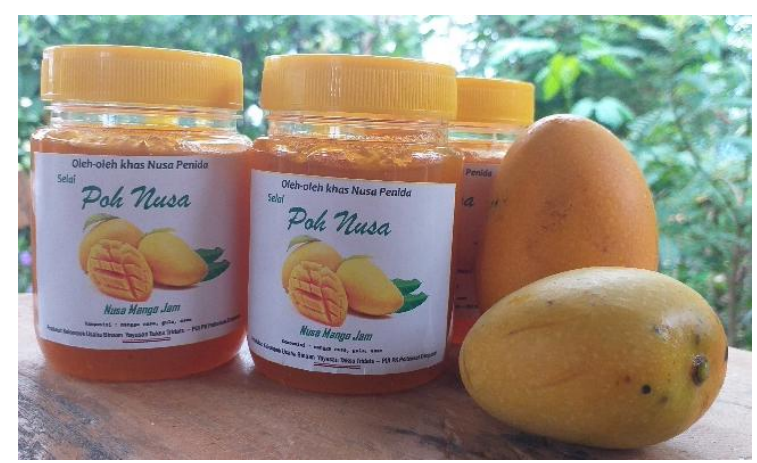

Gambar 1. Selai Poh Lembongan

Hasil pemeriksaan kimia disajikan pada Tabel 1.

Tabel 1. Kandungan Gizi Selai Poh Lembongan "Mangga Nusa"

\begin{tabular}{lr}
\hline \multicolumn{1}{c}{ Kandungan } & \multicolumn{1}{c}{ Kadar } \\
$(\%)$
\end{tabular}

Meditory | ISSN Online : 2549-1520, ISSN Cetak : 2338 - 1159, Vol. 9, No. 1, Juni 2021 
Karta, I.W., dkk.: Analisis Kandungan Gizi Selai Poh Lembongan Oleh-Oleh Langka Khas Nusa Penida

Hasil Uji organoleptik dengan 15 orang panelis ditampilkan pada Gambar 2.

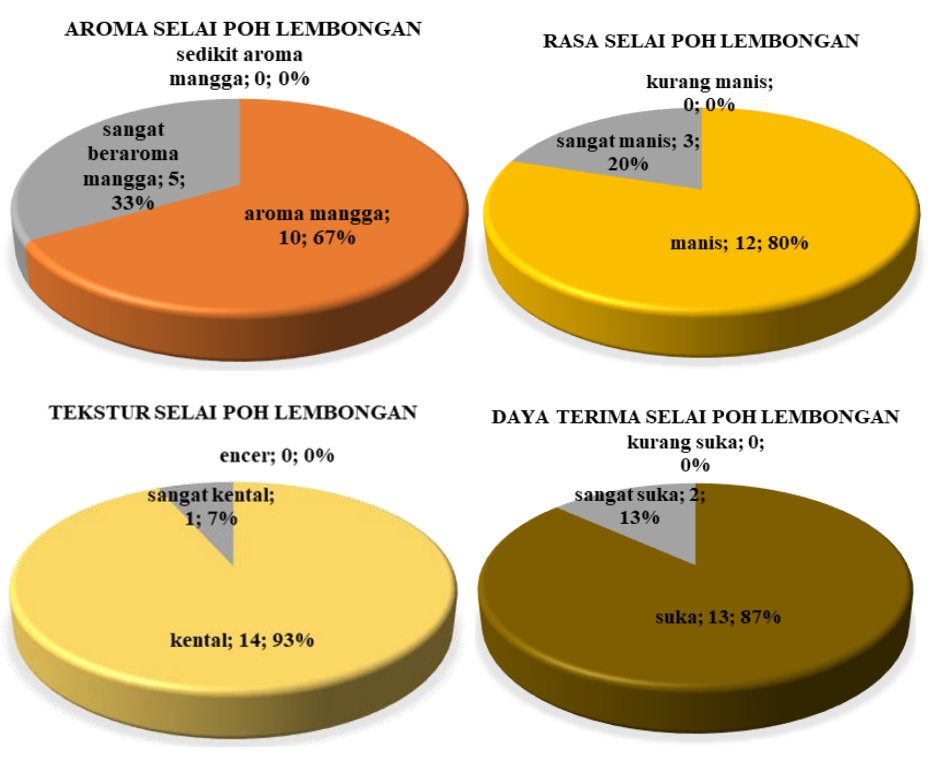

Gambar 2. Hasil uji organoleptik Selai Poh Lembongan

Berdasarkan Gambar 1, selai dari mangga Nusa berwarna kuning jingga. Warna yang kuning ini akan memberikan daya tarik untuk dikonsumsi. Warna produk akan menentukan kualitas atau derajat penerimaan suatu bahan pangan. Penilaian terhadap rasa yang enak dan tekstur yang sangat baik juga membutuhkan warna yang menarik, sehingga konsumen menjadi terkesan $^{(7)}$. Warna selai berbeda dengan warna campuran awal yang berwarna kuning seperti mangga matang. Perubahan warna ini tentu diakibatkan olehnya adanya perubahan suhu saat pemasakan sehingga dapat mengubah warna mangga dan gula. Pada saat proses pemasakan terjadi penguapan air dan gula mengalami karamelisasi gula. Selain itu, dalam proses pemanasan bubur buah dengan gula akan terjadi reaksi maillard. Reaksi ini melibatkan senyawa antara gugus asam amino dengan gula reduksi ${ }^{(8)}$. Proses ini menyebabkan selai poh lembongan menjadi berwarna kuning jingga.

Selai poh lembongan memiliki kadar air sebesar 19,649 \% dan masih sesuai standar selai dari Standar Nasional Indonesia karena kadar air maksimum selai buah menurut SNI 3746:2008 adalah 35\% ${ }^{(9)}$. Air dalam produk olahan akan mempengaruhi kekentalan, tekstur dan ketahanannya terhadap cemaran biologis ${ }^{(10)}$. Kadar air dalam pangan selai sangat menentukan konsistensi tekstur, kesegaran, daya awet pangan ${ }^{(2)}$. Dengan nilai kadar air pada poh lembongan yang relatif kecil, maka akan memberikan dampak terhadap daya simpan produk dan kualitas kekentalannya.

Kadar abu selai poh lembongan yaitu $0,165 \%$. Kadar abu ditentukan untuk mengetahui adanya kandungan mineral suatu bahan ${ }^{(11)}$. Selain itu juga untuk mengetahui kemurnian dan kebersihan bahan yang dihasilkan. Kadar abu tidak selalu ekivalen dengan bahan mineral, hal ini karena kemungkinan ada proses volatilisasi atau interaksi antara penyusun bahan, sehingga ada kehilangan beberapa mineral. Selai poh lembongan memiliki kadar abu yang rendah yang menunjukkan sedikitnya kandungan mineral dalam selai. Selai yang berasal dari buah-buahan pada umumnya hanya kaya akan vitamin 
Karta, I.W., dkk.: Analisis Kandungan Gizi Selai Poh Lembongan Oleh-Oleh Langka Khas Nusa Penida

sementara kandungan mineral seperti kalsium ada hanya dalam jumlah kecil ${ }^{(12)}$.

Selai poh lembongan memiliki kadar lemak sebesar 0,573\% dan kadar protein $0,907 \%$. Kadar lemak pada selai ini termasuk sangat rendah. Kadar lemak yang rendah ini karena memang tidak ada penambahan minyak dalam selai. Jumlah lemak yang rendah tentu sangat baik bagi masyarakat yang memiliki kadar kolesterol yang tinggi. Pektin merupakan karbohidrat kompleks alami yang ditemukan pada dinding sel semua tumbuhan. Pektin dalam buah mangga akan berikatan dengan protein, sehingga membantu dalam membentuk gel dan dapat menstabilkan protein.

Kadar karbohidrat total merupakan pengurangan dari jumlah air total, protein total, lemak total, dan abu total kadar sampel dari $100 \%$ jumlah sampel. Selai poh lembongan memikili kadar karbohidrat total sebesar $78,705 \%$. Kadar yang tinggi ini pada selai dipengaruhi oleh penambahan gula dan kandungan kabohidrat pada mangga poh lembongan. Jenis mangga ini pada saat matang memiliki rasa yang manis yang menunjukkan tingginya karbohidrat dalam buah. Dengan tingginya kandungan karbohidrat ini menyebabkan warna selai menjadi kuning jingga saat dipanaskan. Jika dilakukan sampai sangat kental tentu akan memberikan warna cokelat. Proses pemanasan saat pembuatan selai menyebabkan terjadinya suhu yang tinggi melampui titik lebur sukrosa dan terjadinya karamelisasi. Pada penelitian selanjutnya perlu dilakukan uji gula reduksi pada mangga poh lembongan dan hasil olahan yang dibuat, sehingga diketahui perbedaan kandungan gizi setelah proses pengolahan.

Kandungan vitamin $\mathrm{C}$ pada selai mangga poh lembongan yaitu 20,476\%. Vitamin C sangat dibutuhkan dalam asupan makanan untuk mempertahankan tubuh tetap sehat ${ }^{(13)}$. Vitamin C memainkan peranan penting dalam menjaga respons antioksidan metabolik, serta menghindari terjadinya kerusakan oksidatif yang berimplikasi patologis pada kesehatan manusia $^{(14)}$. Berdasarkan hasil penelitian menunjukkan masih adanya vitamin $\mathrm{C}$ dalam selai mangga poh lembongan. Vitamin ini sebenarnya mudah mengalami reaksi oksidasi yang dapat dipercepat dengan adanya suhu. Adanya pektin dalam mangga yang mempunyai sifat menyerap air dan komponen-komponen yang terlarut di dalamnya, termasuk vitamin $\mathrm{C}$, sehingga vitamin ini akan menjadi lebih stabil. Adanya vitamin $\mathrm{C}$ dalam selai mangga poh lembongan akan memberikan nilai guna bagi kesehatan, sehingga sangat baik dikembangkan menjadi oleh-oleh khas Nusa Penida. Selain itu, vitamin C dalam selai akan memberikan peningkatan daya simpan selai.

Selai mangga poh lembongan dapat dikembangkan menjadi salah satu produk oleh-oleh khas Nusa Penida. Hal ini 
Karta, I.W., dkk.: Analisis Kandungan Gizi Selai Poh Lembongan Oleh-Oleh Langka Khas Nusa Penida

berdasarkan dari uji organoleptik yang telah dilakukan. Aroma mangga masih terasa pada selai mangga poh lembongan. Adanya aroma alami dari mangga akan memberikan rasa kelezatan tersendiri pada makanan. Sebanyak $67 \%$ atau 10 orang menyampaikan aroma selai mangg poh lembongan masih ada dan 5 orang atau 33\% menyatakan aromanya sangat kental mangganya. Peningkatan aroma ini karena pemekatan yang dilakukan dengan pemanasan. Semakin kental selainya, aroma mangganya makin tercium keras. Aroma memiliki peranan yang penting terhadap produk olahan pangan. Hal ini karena akan memberikan hasil penilaian terhadap diterima atau tidaknya produk tersebut di masyarakat. Aroma ini juga memberikan keinginan konsumen untuk mengkonsumsi produk selai mangga poh lembongan.

Rasa selai mangga poh lembongan adalah manis. Rasa manis ini diakibatkan oleh rasa mangga matang yang memang manis dan ditambah dengan pencampuran dengan gula. Penambahan gula selain untuk meningkatkan rasa manis, juga untuk memperbaiki warna dan meningkatkan daya awet. Gula dalam proses pembuatan selai adalah untuk membentuk tekstur gel yang baik, kenampakan produk yang menarik serta memberikan rasa dan flavor. Interaksi gula degan pektin pada buah mangga akan membentuk gel. Pektin dan air akan dipengaruhi keseimbangannya dengan penambahan gula. Kemudian pektin mengalami penggumpalan dan membentuk suatu serabut halus ${ }^{(15)}$.

Kualitas produk olahan sangat ditentukan oleh rasa. Rasa manis pada selai secara umum masih disukai oleh masyarakat. Hal ini karena selai biasanya sebagai pendamping roti tawar, sehingga rasa manis memberi rasa pada roti tersebut. Selai mangga poh lembongan, selain rasanya manis, juga masih memiliki rasa khas mangga Nusa Penida yaitu manismanis dengan sedikit asam.

Tekstur selai poh lembongan yang dihasilkan adalah kental. Kekentalan ini berhubungan dengan kandungan pektin dalam mangga dan interaksinya dengan gula yang ditambahkan. Kualitas selai yang baik harus memiliki daya oles yang baik dan tidak terlalu encer. Penambahan gula selain meningkatkan rasa manis juga berfungsi meningkatkan kekentalan gel pada selai. Gula dapat menyerap air saat pemanasan dan meningkatkan daya simpan selai. Produk menjadi lebih awet akibat air dalam air terperangkap, sehingga air untuk pertumbuhan mikroba menjadi rendah. Ini juga ditandai dengan kadar air selai poh lembongan rendah serta nilai angka lempeng totalnya $<3$.

Berdasarkan penilaian aroma, rasa, dan kekentalan, maka selanjutnya dilakukan uji daya terima produk. Sebanyak $87 \%$ panelis menyatakan kesukaannya dan $13 \%$ menyatakan sangat suka selai mangga poh 
Karta, I.W., dkk.: Analisis Kandungan Gizi Selai Poh Lembongan Oleh-Oleh Langka Khas Nusa Penida

lembongan. Hal ini merupakan suatu potensi dari selai mangga poh lembongan menjadi salah satu produk oleh-oleh khas Nusa Penida. Kandungan gizinya baik untuk kesehatan dan dibutuhkan berbagai macam penelitian lanjutan dari produk ini seperti kombinasi dengan buah lokal lainnya, pengujian viskositas, dan uji pemanfaatannya terhadap kesehatan. Selain itu penelitian mengenai perbandingan pre dan post olahan pangan perlu dilakukan dan jumlah energi yang dihasilkan diharapkan dapat dilakukan penelitian berikutnya.

\section{Kesimpulan}

Selai mangga poh lembongan memiki warna kuning jingga. Kandungan selai ini yaitu kadar air 19,649\%; kadar abu $0,165 \%$; kadar lemak 0,573\%; kadar protein 0,907\%, kadar karbohidrat 78,705\%, serta vitamin C sebesar 20,476\%. Uji organoleptik menunjukkan bahwa rasa, aroma, tekstur bisa diterima oleh masyarakat.

\section{Daftar Pustaka}

1. Utomo RC, Elly I, Sani Y, Si M, Sri I, Si M, et al. Konsentrasi Gula Pasir Terhadap Karakteristik Fisikokimia Dan Organoleptik Selai Timun Krai (Curcumis sp). J Teknol Pangan dan Has Pertan. 2020;15(1):1-4.

2. Gaffar R, Lahming, Rais M. Pengaruh Konsentrasi Gula Terhadap Mutu Selai Kulit Jeruk Bali (Citrus maxima). J Pendidik Teknol Pertan. 2017;3:117-25.

3. Damayanti IAKW, Wijaya IN, Kanca IN. Strategi Pengembangan
Pulau Nusa Penida Sebagai

Kawasan Pariwisata Yang

Berkelanjutan. SOSHUM J Sos

DAN Hum. 2015;5(2):136-45.

4. Sudarmadji S, Bambang H, Suhardi. Prosedur Analisa Untuk Bahan Makanan dan Pertanian. 1997.

5. Vuong Q, Hirun S, Chuen T, Goldsmith C, Bowyer M, Chalmers A, et al. Physicochemical composition, antioxidant and antiproliferative capacity of a lilly pilly (Syzygium paniculatum) extract. J Herb Med. 2014 Sep 1;4.

6. Fathnur. Uji Organoleptik Selai Mangga (Mangifera indica L.) Dengan Penambahan Jahe Dan Gula Aren. J Agrisistem. 2019;15(2):8792.

7. Suneth NA, Tuapattinaya PMJ. UJI ORGANOLEPTIK SELAI BUAH SALAK ( Salacca edulis REINW) BERDASARKAN PENAMBAHAN GULA. Biopendix. 2016;3(1):40-5.

8. Yanto T, Karseno, Purnamasari MMD. Pengaruh Jenis Dan Konsentrasi Gula Terhadap Karakteristik Fisikokimia Dan Sensori Jelly Drink. J Teknol Has Pertan. 2015; VIII(2):123-9.

9. Badan Standar Nasional. SNI 3746:2008 Selai Buah. 2008.

10. Blahovec J. Role of water content in food and product texture. Int Agrophysics. 2007;21:209-15.

11. Afrizal F, Pato U. Pemanfaatan Buah Nipah (Nypa fruticans) Sebagai Bahan Baku Pembuatan Selai. JOM FAPERTA UR. 2017;4(1):1-11.

12. Saputro TA, Permana IDGM, Yusasrini NLA. PENGARUH PERBANDINGAN NANAS (Ananas comosus L. Merr.) DAN SAWI HIJAU (Brassica juncea L.)

Meditory | ISSN Online : 2549-1520, ISSN Cetak : 2338 - 1159, Vol. 9, No. 1, Juni 2021 
Karta, I.W., dkk.: Analisis Kandungan Gizi Selai Poh Lembongan Oleh-Oleh Langka Khas Nusa Penida

TERHADAP KARAKTERISTIK

SELAI. J ITEPA. 2018;7(1).

13. Nisa SR, Santoso H, Syauqi A.

Analisis Kadar Vitamin C pada

Selai Stroberi ( Fragaria sp.) - Buah

Naga ( Hylocereus costaricensis ). J

Ilm SAINS ALAMI (Known

Nature). 2020;2(2):1-7.

14. Mena P, Micol V, Saura D. Vitamin

$\mathrm{C}$ and the Role of Citrus Juices as

Functional Food. Nat Prod

Commun. 2009;4(5):677-700.

15. Nurani FP. Penambahan Pektin,

Gula, dan Asam Sitrat dalam

Pembuatan Selai dan Marmalade

Buah-Buahan. J Food Technol

Agroindustry. 2020;2(1):27-32. 